\title{
PENINGKATAN PERSEPSI GIZI PADA REMAJA DALAM UPAYA PENCEGAHAN KEJADIAN ANEMIA DI SMK 1 KOTA TEGAL
}

\author{
Juhrotun Nisa ${ }^{1}$, Nora Rahmanindar ${ }^{2}$, Riska Arsita Harnawati ${ }^{3}$ \\ ${ }^{123}$ Diploma III Kebidanan Politeknik Harapan Bersama \\ e-mail: nisa.jn20@gmail.com
}

\begin{abstract}
Abstrak
Anemia merupakan masalah gizi di dunia, khususnya di negara berkembang. Sekitar 50-80\% anemia di dunia disebabkan kekurangan zat besi. Prevalensi anemia pada remaja wanita (usia 15-19 tahun) sebesar 26,5\% dan pada wanita subur sebesar 26,9\%. Berdasarkan hasil Riskesdas 2013, proporsi anemia di Indonesia pada kelompok umur 5-14 tahun adalah sebesar 26,4\%. Tujuan kegiatan pengabdian masyarakat ini yaitu untuk meningkatkan persepsi gizi pada remaja dalam upaya pencegahan kejadian anemia. Kegiatan ini dilakukan dengan cara pengukuran tinggi badan dan berat badan, pemeriksaan $\mathrm{Hb}$ serta memberikan informasi terutama tentang anemia dan gizi seimbang. Setelah informasi diberikan diharapkan dapat meningkakan pengetahuan tentang gizi seimbang dan mengurangi kejadian anemia pada remaja putri terutama di SMK 1 Kota Tegal.
\end{abstract}

Kata Kunci : Anemia, Gizi Remaja

\section{PENDAHULUAN}

Salah satu masalah gizi yang dialami remaja adalah defisiensi zat besi. Remaja memiliki resiko tinggi mengalami anemia karena defisiensi zat besi. Hal ini dikarenakan remaja putri mengalami menstruasi setiap bulannya dan sedang dalam masa pertumbuhan sehingga membutuhkan asupan zatbesi yang lebih banyak. Selain itu, ketidak seimbangan asupan zat gizi juga menjadi penyebab anemia pada remaja. Remaja putri biasanya sangat memperhatikan bentuk tubuh, sehingga banyak yang membatasi konsumsi makanan dan banyak pantangan terhadap makanan. Bila asupan makanan kurang maka cadangan besi banyak yang dibongkar.Keadaan seperti ini dapat mempercepat terjadinya anemia. Anemia juga berpotensi pada remaja vegetarian. Salah satu sumber utama zatbesi adalah daging merah. Berpantang makan daging pada vegetarian akan mengurangi jumlah zatbesi yang masuk ketubuh ${ }^{(1)}$.

Selain itu indeks massa tubuh (IMT) merupakan indikator gizi seseorang, penelitian yang dilakukan oleh Permaesih,menyatakanadahubunganantaraIndeks Massa Tubuhdengan anemia, remajaputridenganIndeks Massa Tubuhkurusmemilikiresiko 1,4 kali menderita anemia dibandingkandenganremajaputridengan IMT normal ${ }^{(2)}$.

Anemia merupakan masalah gizi di dunia, khususnyadi negara berkembang. Sekitar 50-80\% anemia di dunia disebabkan kekurangan zat besi. Prevalensi anemia pada remaja wanita (usia 15-19 tahun) sebesar 26,5\% dan padawanita subur sebesar 26,9\%(3).Berdasarkan hasil Riskesdas 2013, proporsianemia di Indonesia -... kelompok umur 5-14tahun adalah sebesar $26,4 \%{ }^{(4)}$.

Kelompok risiko tinggi mengalami anemia yaitu pada usia remaja, khususnya remaja putri, hal tersebut dikarenakan kebutuhan absorpsi zat besi memuncak pada umur 14-15 tahun sedangkan remajaputra, mengalami puncak absorpsi zat besi satu atau dua tahun berikutnya ${ }^{(5)}$. Faktor risiko utama anemia defisiensi besi adalah asupan zat besi yang rendah, penyerapan 
zat besi yang buruk, dan periode kehidupan ketika kebutuhan akan zat besi tinggi seperti pada masa pertumbuhan, kehamilan, dan menyusui, Selain itu kebutuhan zat besi yang tinggi pada remaja putri juga terjadi pada masa menstruasi ${ }^{(6)}$.

Dampak anemia pada remaja putri dan status gizi yang buruk memberikan kontribusi negatif bila hamil pada usia remaja ataupun saat dewasa yang dapat menyebabkan kelahiran bayi dengan berat badan lahir rendah, kesakitan bahkan kematian pada ibu dan bayi. Selain itu, anemia juga mempunyai dampak negatif terhadap perkembangan fisik dan kognitif remaja ${ }^{(6)}$.

SMK 1 Kota Tegal memiliki siswa yang terdiri dari remaja putra dan remaja putri. Sekolah kejuruan ini merupakan sekolah non kesehatan sehingga siswanya terutama remaja putri belum terpapar masalah kesehatan seperti kejadian anemia. Remaja putri yang telah mengalami menstruasi lebih rentan mengalami anemia, terlebih pada mereka siswa menengah kejuruan (SMK) yang tidak memperoleh materi kesehatan sama sekali. Selain itu banyaknya penjual jajanan disekolah mempengaruhi minat siswi untuk memilih jajanan tersebut dibandingkan dengan asupan gizi yang dibutuhkan oleh mereka setelah seharian fokus belajar, selain itu masih ada kegiatan diluar jam belajar seperti kegiatan ekstrakurikuler.

\section{METODE}

Kegiatan pengabdian kepada masyarakat mengenai peningkatan persepsi gizi pada remaja dalam upaya pencegahan kejadian anemia ini diberikan kepada siswi SMK 1 Kota Tegal.

Proses pelaksanaankegiatanpengabdianmelaluibeberapatahap, yaitu:

1. Pendataanjumlah siswi (remaja putri) yang ada di SMK 1 Kota Tegal melalui bagian kesiswaan SMK 1 Kota Tegal

2. Memilih calon responden

3. Kontrakwaktudenganbagian Kesiswaan SMK 1 Kota Tegal

4. Menyiapkantempat/lokasipelaksanaanPengabdianmasyarakat

5. Mengumpulkanpeserta sebanyak \pm 50 orang remaja putri

Peningkatan pengetahuan siswi tentang gizi pada remaja dan upaya pencegahan kejadian anemia dilakukan dengan cara memberikan informasi dan pendidikan kesehatan terutama tentang gizi, anemia, waktu dan cara tapat untuk meminum zat besi, pemeriksaan kadar hemoglobin dan pengukuran indeks massa tubuh (IMT). Kegiatan dilakukan selama 3 hari yaitu pada hari rabu s/d jum'at tanggal 8-10 Agustus bertempat di SMK 1 Kota Tegal.

Adapun alur pemecahan masalah persepsi gizi remaja dalam pencegahan anemia secara rinci adalah sebagai berikut:

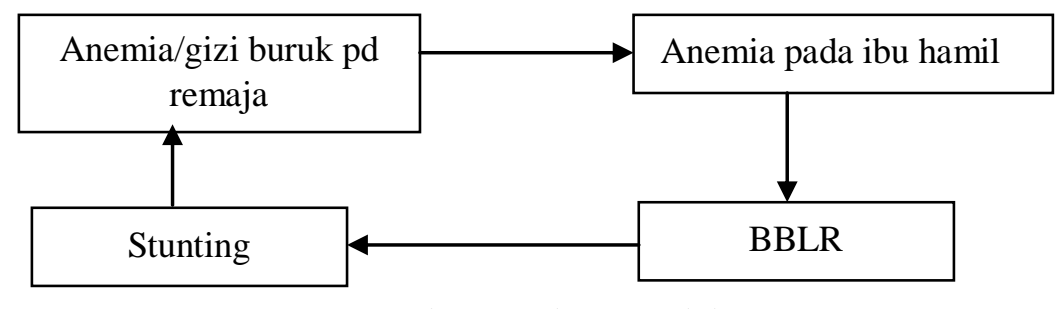

Gambar 1. Alur masalah

Sedangkan alur pemecahan masalah diatas sebagai berikut:

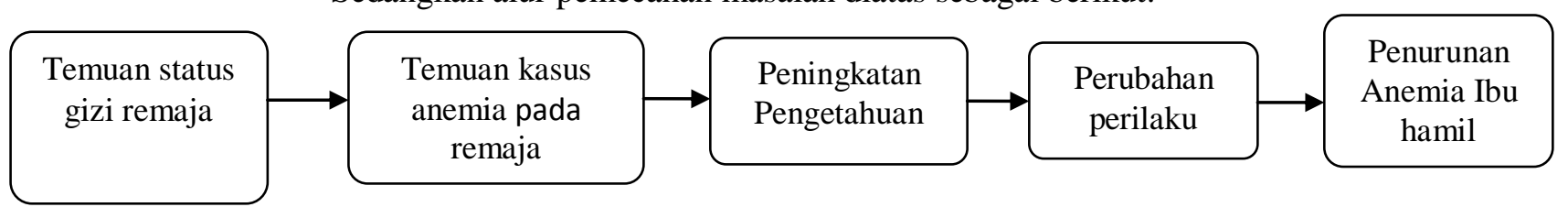

Gambar 1. Alur pemecahan masalah 


\section{HASIL DAN PEMBAHASAN}

Kegiatan pengabdian masyarakat mengenai peningkatan persepsi gizi pada remaja dalam upaya pencegahan kejadian anemia dilaksanakan selama 3 hari. Kegiatan ini diawali dengan pendataan jumlah siswi SMK 1 Kota Tegal yang akan dijadikan responden, pengukuran indeks masa tubuh (IMT) dengan mengukur tinggi badan dan berat badan, pemeriksaan $\mathrm{Hb}$, membagikan kuisioner kepada responden mengenai gizi dan anemia (pretest), memberikan penyuluhan mengenai gizi pada remaja dan anemia, membagikan kuisioner kepada responden mengenai gizi dan anemia (posttest).

Pengukuran berat badan pada remaja putri didapatkan hasil bahwa berat badan terendah $39 \mathrm{~kg}$ dan berat badan tertinggi $75 \mathrm{~kg}$, sedangkan pengukuran tinggi badan diperoleh hasil tertinggi $168,5 \mathrm{~cm}$ dan tinggi badan terkecil $147 \mathrm{~cm}$, sedangkan indeks massa tubuh (IMT) diperoleh nilai terendah 16,4 artinya siswa tersebut memiliki berat badan yang kurang sedangkan nilai IMT tertinggi sebesar 31,2 artinya remaja putri tersebut obesitas.
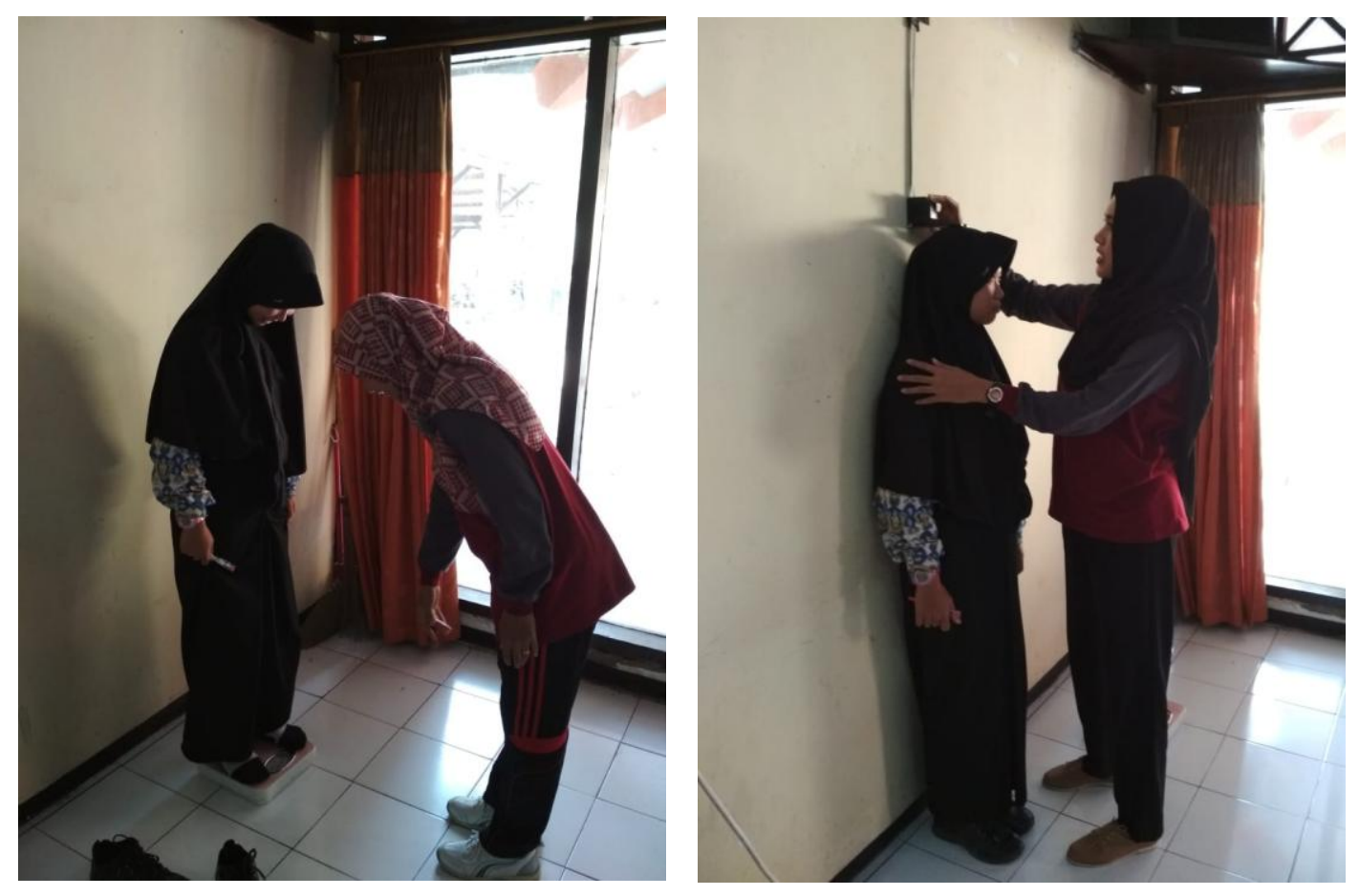

Gambar 3. Pengukuran tinggi badan dan berat badan

Total temuan indeks massa tubuh (IMT) pada 48 siswa meliputi, 12 orang memiliki berat badan yang kurang, 27 orang memiliki berat badan normal, 7 orang memiliki berat badan berlebih dan 2 orang memiliki berat badan dengan grade obesitas. 


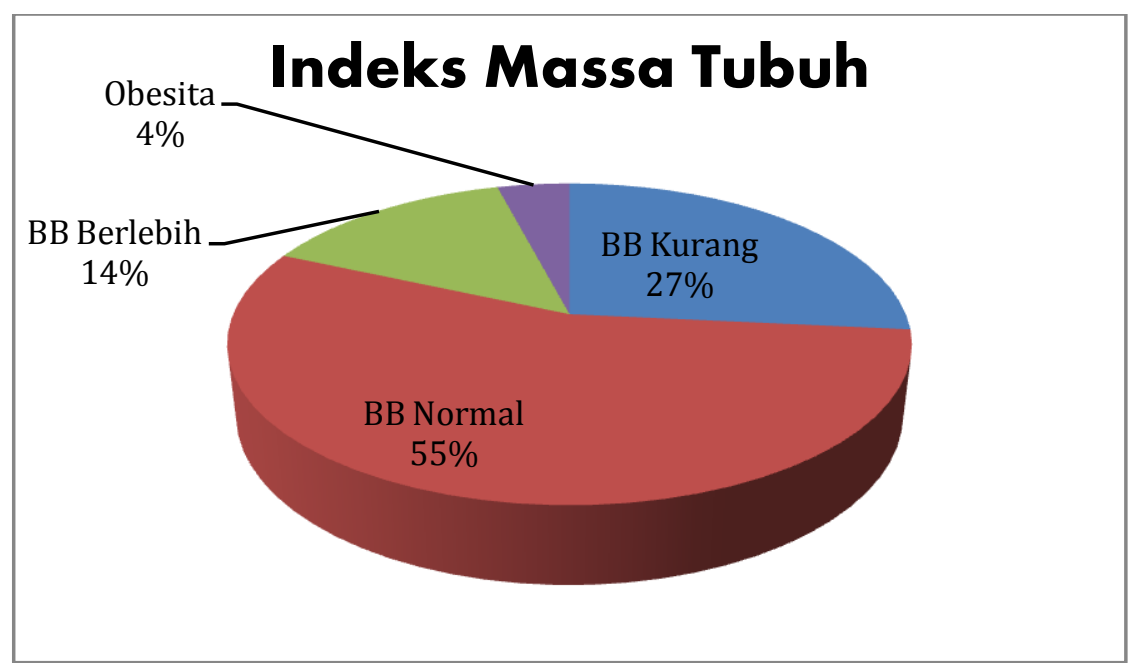

Gambar 4. Indeks Massa Tubuh

Setelah dilakukan pengukuran IMT, kemudian dilakukan pemeriksaan kadar hemoglobin, Pemeriksaan hemoglobin dilakukan dengan tujuan untuk mengetahui kadar hemoglobin dalam darah remaja putri di SMK 1 Kota Tegal. Hasil pemeriksaan yang dilakukan menunjukan hasil kadar $\mathrm{Hb}$ terendah 11 gr\% dan kadar tertinggi 17,8 gr\%,dengan temuan kasus 6 orang menderita anemia, dan 42 orang lainnya tidak mengalami anemia, hal tersebut sesuai dengan teori Kadar $\mathrm{Hb}$ normal padaremajaputriadalah $12 \mathrm{gr} / \mathrm{dl}^{(1)}$.

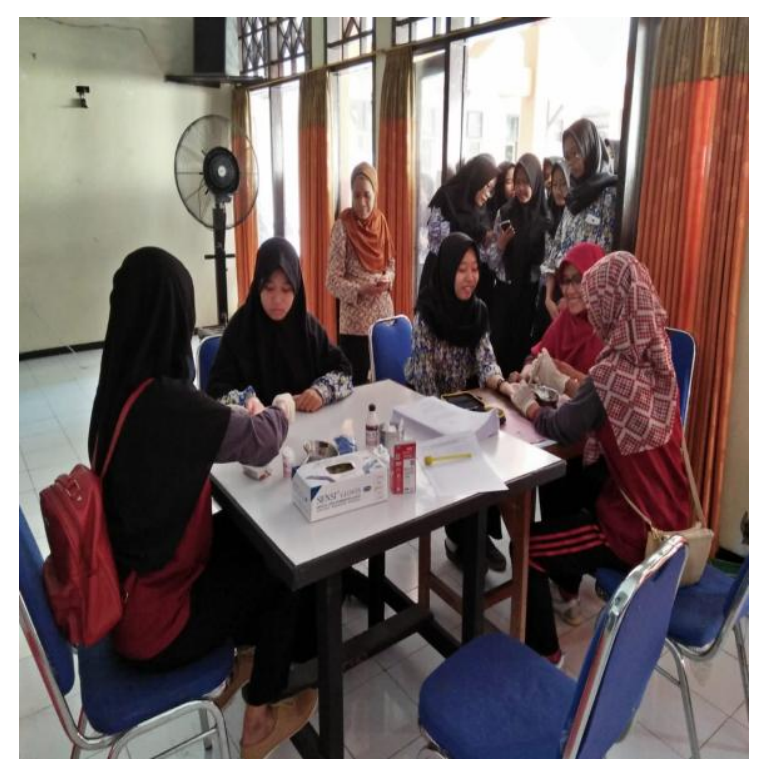

Gambar 5. Pemeriksaan Hemoglobin

Mayoritassiswi dalam kegiatan ini belelum mengetahui tentang gizi maupun anemia.Dalamkegiatanpengabdianmasyarakatini, para siswi diajarkan cara meminum zat besi sehingga bisa lebih efektif untuk mengurangi resiko anemia. 




Informasi dan pendidikan kesehatan ini diberikan untuk meningkatkan pengetahuan remaja putri tentang pentingnya gizi dan dampak jika mengalami anemia, sehingga kejadian anemia dan kelahiran bayi dengan berat badan rendah dapat dicegah.



Gambar 7. Pemberian informasi tentang gizi dan anemia

Sebagian besarsiswa memiliki pengetahuan rendah tentang gizi dan anemia. Hal ini dibuktikan dengan hasil pengisian kuisioner bahwa sebanyak 20 siswi tidak mengetahui tentang anemia dan sebanyak 23 siswi tidak mengetahui tentang anemia. Semakin banyak sumber informasi yang dimiliki maka tingkat pengetahuan yang dimiliki semakin tinggi.

Setelah diberikan penyuluhan oleh pemateri mengenai gizi dan anmeia, terlihat adanya peningkatan pemahaman oleh siswi. Selain mengenai gizi dan anemia, siswi juga mengerti waktu dan cara yang tepat meminum zat besi guna mengurangi resiko anemia.

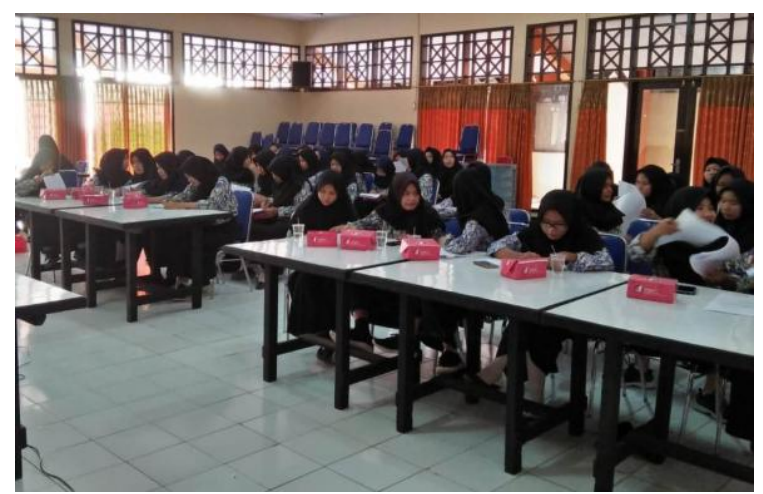

Gambar 8. Posttes penyuluhan gizi dan anemia 
Data Sebelum dan SesudahPenyuluhan(Posttest):

\begin{tabular}{|c|c|c|c|c|c|c|c|}
\hline \multirow[t]{2}{*}{ No. } & \multirow[t]{2}{*}{ Materi } & \multirow[t]{2}{*}{ Ket. } & \multicolumn{3}{|c|}{ NILAI } & \multirow{2}{*}{$\begin{array}{l}\text { Rata- } \\
\text { Rata }\end{array}$} & \multirow{2}{*}{$\begin{array}{l}\text { Pening- } \\
\text { katan }\end{array}$} \\
\hline & & & Baik & Cukup & Kurang & & \\
\hline \multirow[t]{2}{*}{1.} & \multirow[t]{2}{*}{ Anemia } & Pretest & 9 & 19 & 20 & 62,25 & \multirow[t]{2}{*}{16,92} \\
\hline & & Posttest & 24 & 24 & 0 & 79,17 & \\
\hline \multirow[t]{2}{*}{2.} & \multirow[t]{2}{*}{ Gizi } & Pretest & 4 & 21 & 23 & 52,08 & \multirow[t]{2}{*}{17,92} \\
\hline & & Posttest & 20 & 25 & 3 & 70,00 & \\
\hline
\end{tabular}

\section{KESIMPULAN}

Kegiatan penyuluhan dan pemeriksaan ini dilakukan sebagai sarana untuk melakukan skrining gizi, memberikan informasi, meningkat kanpengetahuan, sikap dan perilaku remaja putri tentang gizi dalam melakukan pencegahan anemia. Hasil pemeriksaan menunjukan bahwa sebagian besarremaja putri memiliki nilai indeks massa tubuh 18,5 - 22,9 sebanyak 27 orang atau dengan kata lain 56,25\% remaja putri di SMK 1 Kota Tegal memiliki berat badan normal, 42 orang (88\%) tidak mengalami anemia dan terjadi peningkatan pengetahuan setelah dilakukan penyuluhan.

\section{SARAN}

Hendaknya ada pemeriksaan rutin dan monitoring IMT dan kadar $\mathrm{Hb}$ untuk pencegahan anemia pada remaja. Selain itu diharapkan remaja putri lebih mematuhi waktu dan cara untuk mengkonsumsi zat besi.

\section{DAFTAR PUSTAKA}

[1] Proverawati. (2011). Anemia dan Anemia kehamilan.NuhaMedika. Yogyakarta.

[2] Permaesih D, S Herman. 2005. Faktor-faktor yang mempengaruhi anemia pada remaja. BuletinPenelitianKesehatan.

[3] Departemenkesehatan RI, 2005. Gizi dalam Angka. Jakarta:Departemen Kesehatan

[4] KementrianKesehatan RI, 2014. Riset Kesehatan Dasar 2013. Jakarta: KementerianKesehatanRepublik Indonesia.

[5] WHO, 2011. Prevention of Iron Deficiency Anemia in Adolescents: Role of WeeklyIron and Folic Acid Suplementation.

[6] WHO, 2008. Worldwide Prevalence of Anemia 1993-2005: WHO Global Databaseon Anemia. 